\title{
Friendship Policies in Russian Religious Philosophy
}

\author{
Vladimir Bystrov \\ Doctor of Philosophy, Professor, Saint Petersburg University \\ Address: Universitetskaya nabereznaya, 7/9, Saint Petersburg, Russian Federation 199034 \\ E-mail: vyb83@yandex.ru \\ Sergei Dudnik \\ Doctor of Philosophy, Professor, Saint Petersburg University \\ Address: Universitetskaya nabereznaya, 7/9, Saint Petersburg, Russian Federation 199034 \\ E-mail: s.i.dudnik@gmail.com \\ Vladimir Kamnev \\ Doctor of Philosophy, Professor, Saint Petersburg University \\ Address: Universitetskaya nabereznaya, 7/9, Saint Petersburg, Russian Federation 199034 \\ E-mail: kamnev4@yandex.ru
}

\begin{abstract}
In antiquity, the phenomenon of friendship became the object of steadfast attention from philosophy. In Nicomachean Ethics, Aristotle connects the political existence of man with friendship since he believes the city (polis) can be built in analogy with friendly unions. Cicero also saw a social prototype in friendship. A gradual change in such a representation resulted in a romantic concept of friendship that is understood as the subjective, sensual bringing together of individuals, but is only accessible to few. Kant and Hegel also adhered to the romantic concept. Russian religious philosophy, on the one hand, is formed under the influence of German romanticism and the understanding of friendship peculiar to it, but, on the other hand, it returns immediately to the concept of friendship as a social construct. Khomyakov believes that friendship is first of all established between the power and the people, and this friendly union distinguishes Russian culture from the West European culture. However Russian religious-philosophical thought is distinguished by the aspiration to understand the phenomenon of friendship not in itself, but in its connection with the concepts of enmity and brotherhood. There is an image of brotherly unity emanating from a Far Eastern civilization which Vl. Solovyov posits as the main threat to Christianity, whereas N. Fyodorov, believes that a brotherly unity and an unspoken pledge of rescue from "the not brotherly" West that has remained in the Russian and in the Chinese agrarian communities. The relationship between the concepts of friendship and brotherhood becomes clearer in $20^{\text {th }}$ century Western European thought, particularly in the representations of the "mystical acosmism of brotherhoods" by the sociologist and philosopher M. Weber and the political philosopher H. Arendt.
\end{abstract}

Keywords: friendship, political, enmity, brotherhood, Russia, Europe, East, acosmism

In classical antiquity, the phenomenon of friendship became a subject of profound philosophical study. Aristotle distinguished three types of friendship, the friendship of utility, the friendship of pleasure, and the friendship of the good, with the friendship of the good being regarded as the fullest and best form of friendship as it is linked with the

\footnotetext{
(C) Vladimir Bystrov, 2016

(C) Sergei Dudnik, 2016

(C) Vladimir Kamnev, 2016

(C) Centre for Fundamental Sociology, 2016
}

DOI: $10.17323 / 1728-192 \mathrm{X}-2016-4-114-129$ 
moral improvement of the human being (Aristotle, 2004). Using the language of modern philosophy, it means that the phenomenon of friendship presents an important ethical, anthropological, and, following from Aristotle's reasoning, a political problem. Friendship is seen as an embodiment of virtue since a dialogue of philosophers offers a greater measure of wisdom in terms of quantity as well as quality than any of its participants. On the other hand, a military alliance ("hetairos") offers a measure of bravery exceeding that of the most courageous warrior. Friendship of the good does not exclude the other two types of friendship. Rather, it encompasses friendship of utility and friendship of pleasure, combining and satisfying all human desires in full.

Cities (poleis) and communities are also based on the bonds of friendship. Moreover, Aristotle holds that the three types of friendship correspond to three forms of constitution (ruling systems), as well as their corrupted and perverted versions. The friendly relations between father and son correspond to kingship; the friendship between husband and wife corresponds to aristocracy, while timocracy can be compared with the friendship between brothers; with tyranny, on the other hand, the friendship between rulers and the ruled becomes impossible. In Aristotle's philosophy, the different types of friendship provide the best model for describing political systems, and what is readily understandable about friendships between individuals can be extrapolated onto state regimes. Cities are also built around friendships, so the political importance of friendship for Aristotle is without doubt.

Aristotle begins his reasoning with the question of whether friendship is a positive attribute or if it arises from deprivation (a lack of communication, the weakness of an individual in need of external support, etc.). Aristotle and Cicero both see friendship as a prototype of sociality as such. Friendship is preferable to any form of human collectivity such as the tribe, a civil community, or a community based on blood kinship. Cicero writes "But of all the bonds of fellowship, there is none friendship, more noble, none more powerful than when good men of congenial character are joined in intimate friendship; for really, if we discover in another that moral goodness on which I dwell so much, it attracts us and makes us friends to the one in whose character it seems to dwell" (Cicero, 1913: 59). Cicero's well-known and often-quoted work does not add anything radically new to Aristotle's understanding of friendship.

The Aristotelian concept of friendship has a complex history in philosophy. In Immanuel Kant's ethic, the reality of friendship is questioned as "friendship is only an Idea (though a practically necessary one) and unattainable in practice, although striving for friendship (as a maximum of good disposition toward each other) is a duty set by reason, and no ordinary duty but an honorable one (Kant, 1991: 261). Additionally, Hegel limits the possibility of friendship to young age, while in the age of maturity "it is inherent essentially in the principle of our deeper life that, on the whole, every man fends for himself, i.e., is himself competent to take his place in the world" (Hegel, 1975: 1154). This understanding of friendship was predetermined by the Romantic canon, which is clearly elitist in nature. This elite, subjective, and ecstatic character of the Romantic ideal of friendship largely ignored friendship's sociogenic and political (i.e., polis-building) 
content. In the modern age, few would dare support Aristotle's statement that a political system must be understood through the type of friendship it is based on.

German Romanticism has been acknowledged of having a decisive effect on the development of Russian religious philosophy (Vorobyeva, 2015; Maslin, 2016; Sizemskaya, 2012; Filatova, 2010). It is all the more surprising that the Romantic canon of friendship did not attract any considerable interest among Russian philosophers. Instead, friendship is interpreted as a phenomenon characterizing society in general rather than subjective aspects of interpersonal relations. This interpretation is placed in an unusual for the early $19^{\text {th }}$ century context, linking the idea of friendship with both its opposite (enmity) and the phenomenon of brotherhood. The context forms itself spontaneously, and is seen as natural by Russian religious philosophy which does not attempt to reflect on the origins of this context or even recognize its uniqueness. As Russian religious philosophy places all three concepts ("friend," "enemy," and "brother") into the field of political relations, these concepts and the specific links between them are relevant to the interpretation of the category of the political in Russian philosophy. In this interpretation, the political is constructed not only along the "friend-enemy" axis, but also along the intersections formed by each member of this binary with ideas and practices of brotherhood. This diversity enables us to talk of friendship policies rather than a single policy. It should be noted that Western European philosophy turned to friendship policies much later, during the second half of the $20^{\text {th }}$ century (Blanchot, 1971; Derrida, 1994).

At the same time, there are grounds to believe that the phenomenon of friendship and its interpretation by Russian religious philosophers are crucial to understanding the historical development of Russian religious philosophy as a whole. According to a belief shared by many Russian religious philosophers, the principal value of philosophy lies in metaphysics, i.e., in the holistic, extrasensory, and free knowledge of universal truths. It is implied that prominent philosophers must necessarily have recourse to intense metaphysical experiences, and are able to find the absolute and the metaphysical principle in everything. The only question that remains is whether this ability to find absolutes is a personal achievement of each philosopher, a gift not unlike a poetic genius celebrated by Romantic authors, or whether it characterizes philosophical knowledge irrespective of who approaches it. Russian religious philosophy clearly gravitates to the former viewpoint. However, to openly recognize that metaphysical gift characterizes an individual philosopher as a "living psychological being" would mean acknowledging the dependence of metaphysics from psychology and experience, and, consequently, the dependence of the eternal and absolute on the transient and relative. In this case, the methodology used by philosophy to comprehend the absolute would have to be made explicit, something Russian religious philosophy has consistently refrained from doing throughout its history.

It should be acknowledged that Russian humanitarian knowledge is frequently constrained by the exaggerated and inadequate understanding of the role of Russian religious philosophy in the Russian ideological atmosphere of the $19^{\text {th }}$ and early $20^{\text {th }}$ centuries. Sometimes this understanding is described via an impressive metaphor: "Russian reli- 
gious philosophy is the Biblical spirit of creation hovering above the waters of our chaotic existence" (Mailov, 1997: 11). Nevertheless, the intention to present Russian religious philosophy as the sole carrier of the creative principle in Russia can be easily put into doubt. As a matter of fact, the ordering and differentiating principle must itself be orderly and differentiated if we are to regard philosophy as a science rather than as practical wisdom. One cannot fail to notice that the phenomenon of friendship for Russian religious philosophy is, on the one hand, too simple to look for the absolute in it, and on the other hand, too tightly linked with common sense to become a primary object of study for emerging scientific philosophy. The study of friendship is a domain where the simplicity and even naiveté of Russian religious philosophy is manifested in full. Yet, this very simplicity may have enabled us to identify the connections between friendship, enmity, and brotherhood which will later serve as an object of reflection for Western European philosophy.

The friendship concept first emerges as a historiosophical problem in the works by Aleksey Khomyakov. His article "About the Old and the New" argues that social relations in Russia cannot be effectively regulated by legal mechanisms. Khomyakov believes that the Russian soul is home to beautiful traditions which, however, have receded and faded away in the collective memory. The moral significance of these traditions resulted in a friendship between the people and state leadership (vlast'). There was a period when the social system was based on the law of justice and mutual love:

The state leadership proves its own existence through the growing influence of
Russia and through the fact that Russia has managed to triumph over numerous
strong enemies; friendship between the state leadership and people [italicized by us]
is manifested in an old custom which had survived until the reign of Tsar Aleksey
Mikhailovich when representatives of all social classes assembled to discuss issues
of state importance. (Khomyakov, 1994: 458)

For Khomyakov, this friendship between the Russian state leadership and the Russian people is a unique phenomenon in the history of humankind. The friendship forms the essence of Russian political organization, and ensures an effective substitute for the institutions of European representative democracy. What is crucial, though, is that the bond of friendship between the state leadership and the people has enabled Russia to defeat many strong enemies. Friendship and enmity are linked into a whole, and mutually reinforce one another. The more enemies, the stronger the friendship between the state leadership and people, and vice versa: the stronger the friendship between the leadership and people, the more dangerous and stronger enemies there are in the outside world. With such reasoning, Khomyakov emphasizes the idea of popular unity while ignoring some obvious historical facts. However, as demonstrated by the history of the Slavophile movement and the whole of Russian conservatism of the $19^{\text {th }}$ century, no amount of historical facts is likely to undermine a convenient concept linking friendship and enmity.

The friendship between the state leadership and the people is based on the same mechanism as church unity. Georges Florovsky pointed out that Khomyakov and the Slavophiles shared a type of natural ecclesiology revolving around a charismatic pastor 
(a role filled by Christ during the times of the Gospels), or "starets" (literally, "elder," or a spiritual mentor), who revitalized souls owing not so much to his position in the hierarchy and the related authority of one that administers sacraments (Florovsky, 1991) as to the existential penetration into the soul of the mentee by joining him in active and compassionate love. This motif resonates with Khomyakov's ideas concerning the "love bondю” However, while Khomyakov focuses on brotherly love, emphasizing the equality of parties in friendship, the $2 \mathrm{O}^{\text {th }}$ century theological concepts see the pastor as a "strong personality," or a "superman" capable of absorbing the personality of the other and transcending this otherness, although commonly interpreted as a consequence of sinful selfisolation.

Khomyakov used the Romantic ideal of friendship built on equality and reciprocity as his point of reference. He reproaches Western Christians of "spiritual fratricide" where the bonds of friendship between Christians are neglected and replaced by authority. The theme of friendship as an important phenomenon to Christianity will be further elaborated by Pavel Florensky in The Pillar and Ground of the Truth (Letter 11) (Florensky, 2012). Led by Florensky's example, Sergei Bulgakov also addresses the concept of friendship, following the trend started by Khomyakov, writing:

Friendship is a personal relation in love, rooted in the life of the Church.... Even though the relations of friendship have a pairwise character in each particular case, they can be repeated since one and the same person can enter into different alliances of friendship; and a natural hierarchy is established among these alliances such that one true Friendship is realized among many friendships and friends.... The foundation of churchly friendship is Christ's Friendship with us. He tells His disciples: "Ye are My friends . . . I have called you my friends; for all things that I have heard of my Father I have made known unto you' (John 15:14, 15)." (Bulgakov, 2003: 317)

Yet, the ideal of friendship between the state leadership and the people, as well as the ideal of church unity, are only loosely linked with reality. Khomyakov shares a Platonic conviction that church unity or the friendship between the people and state leadership are only incomplete analogues or copies of the respective original ideas. The rational discernment of ideal essences is made possible by the perseverance of the community ("soborny") spirit in Russian history; however, no evidence was provided that this spirit persevered in the first place. Like Khomyakov, Aksakov failed to see that

in the Moscow state, these consultative forms of governance were superseded by purely Tatar slavery from top down, from the first boyar to the last peasant-something Aksakov would not see. He created a fantastical idyll without thinking that this idyll destroyed the spiritual wholeness which Slavophiles regarded as the main characteristic of the Slavs: thought and will were attributed to different entities-an impossible relationship under any political system, which inevitably led to the suppression of free thinking. And yet, this ugly fantasy was offered as an example for all nations. (Chicherin, 2009: 201) 
According to Khomyakov, enmity as an opposite of friendship is the last barrier to universal well-being. The history of humankind is full of enmity; constant disagreements between ancient gods symbolize the eternal enmity between peoples and religions. Quite unexpectedly, Khomyakov claims that this law of universal enmity only applies to the West, and logically leads to the universal enmity between West and East (more specifically, between Orthodoxy and Catholicism).

Moreover, along with other Slavophiles, Khomyakov is more interested in the phenomenon of enmity than in friendship. An automated word search in electronic copies of works by Slavophiles shows that the word "enmity" is 3-4 times more prevalent in their writings than the word "friendship" or its derivatives. Nikolay Danilevsky extrapolates the pervasive enmity of the West towards the East from the religious sphere onto the field of intergovernmental relations. "Why is Europe hostile towards Russia?" is the recurrent theme of his well-known book Russia and Europe. In this seminal work, Danilevsky assures his readers that Russia never pursued expansionist policies towards the West. Judging by historical facts, he continues to claim that ethnicities such as the Chud, the Meria, the Ves, or the Mordvins were assimilated peacefully; Ingria was part of Russia since the times of Yaroslav the Wise; the acquisition of Siberia occurred peacefully, with the consent of the indigenous leaders; the Polish lands annexed by Russia historically used to belong to the latter; Finland did not play any dramatic part in history before joining Russia, and its colonization was therefore permissible; the conquest of the Caucasus so widely criticized in Europe was less significant than the annexation of Poland, and numerous wars led by Paul I and Alexander I were consistent with the interests of Europe. Although Danilevsky does admit that the territories of Bessarabia and Crimea were annexed by Russia forcibly and contrary to the wishes of the local population, he stresses that the territories used to be strongholds for the enemies of Russia, and that the annexation of these territories was the only possible choice for Russia. According to Danilevsky, its adversaries often refer to Russia as the world policeman that destroys any emergent areas of freedom, consistently suppressing revolutions in Europe by force. Danilevsky believes, however, that this problem used to be irrelevant prior to the French Revolution since Russia had never previously threatened the liberal achievements of European culture. After the French Revolution, the Russian army, headed by Suvorov, was deployed in Europe, although only for a short while, and only at the request of the European monarchs who feared a mutiny of the Third Estate. In the post-revolutionary period, during the Congress of Vienna which had to decide the future destiny of the defeated France, it was Alexander I that suggested introducing constitutional monarchy in France, despite the efforts of the Europeans Metternich and Talleyrand to restore the French monarchy. Danilevsky writes:

What is the reason for this mutual enmity? Can it be because Europe simply does not know Russia? Then how come Europe, which knows everything from the Sanskrit language to the Iroquois dialects, from the laws of motion of complex systems of stars to the structure of microscopic organisms, does not know only Russia? . . 
Europe does not know Russia because it does not want to know, or, rather, it knows Russia the way it wants to know it, that is, in a way consistent with its preconceptions, passions, pride, hatred and contempt. (Danilevsky, 2011: 43)

Danilevsky argues that Europe, following its "historical instinct," will be reluctant to acknowledge Russia as long as Russia preserves its cultural core which cannot be assimilated by European culture.

Danilevsky sees friendship as an opportunistic political concept required to achieve a temporary truce in the eternal conflict of states and peoples. Enmity is absolute, while friendship is relative. This principle is key to understanding Danilevsky's frequently cited statement of "Differences in political principles cannot serve as a barrier to friendships between governments and nations" (Danilevsky, 2011:36). If the governments are at odds, the people may remain friends; however, these very friendly relations preserved against the will of the governments may later play an important role in peace-making or, alternatively, be used to weaken the hostile government.

Vladimir Solovyov (Soloviev), the loudest and most consistent critic of Danilevsky's historiosophical theory (Solovyov, 1988, 2007: 406-414), examines the same correlation of friendship and enmity. Friendship is only mentioned in connection with international relations; the existence of friendships between countries and peoples must be analyzed depending on whether the alliance is targeted at good or evil. The triumph of enmity over friendship is due to the domination of centrifugal and "divisive" natural forces aiming to break the continuity of human existence and its link with the supreme principles of being. These centrifugal forces rule over individuals and society in general; consequently, relations between peoples and states are hostile rather than friendly. In Solovyov's vision, the epicenter of hostility is associated with the East rather than with Europe.

"The national idea," "the Russian idea," and "the soul of the people" are notions inextricably linked with Solovyov's understanding of the Christian culture. Vyacheslav Ivanov defines Vladimir Solovyov's mission in Russian culture fairly broadly: "Through Solovyov, the Russian nation by means of Logos became aware of its mission - to serve the principle of the Universal Church even at the cost of losing the nation's soul" (Ivanov, 1994: 61). The mission of the Russian people is, therefore, to overcome the schism between religious confessions and establish a single Universal Church. The Russian nation is suited to perform this ecumenical mission. This is due in part to its characteristic responsiveness and sensitivity to issues of world history, and in part to its geographical position, i.e., geopolitical factors like the emergent threat of Pan-Mongolism and the necessity for the Orthodox East and Catholic West to resist Pan-Mongolism with a joint effort. In one of his last works, A Short Tale of the Antichrist, written four years before the Russian-Japanese war, Solovyov outlined the key features of Pan-Mongolism, predicting the future invasion of the Asian hordes in the West with the aim to drive out "the white devils" from Asia, and establish "the true Middle Kingdom" over the whole world. Vladimir Solovyov predicted the future role of East Asia and believed that it is in this region that world history will be made. Russia, being a great fringe district of Europe at the Asian border, is 
destined to play a crucial part in the conflict between West and East. The same factors explain Vladimir Solovyov's critique of Slavophilia, which, in his opinion, rashly opposes the Slavic world to Western Europe. Russians have long made their choice in favor of the West; they are Europeans "with an Asian streak deep in their hearts." He saw $21^{\text {st }}$ century Europe as an alliance of democracies, as "a United States of Europe."

Solovyov linked "the Eastern menace" not so much with the religious tension between Christianity and Islam as with the growing influence of the Far East (the latter was never involved in any conflicts with Russian Orthodoxy in the religious sphere). For Solovyov, the social organization typical of the Far Eastern civilization is deeply alien and potentially hostile to the Christian world, and emanates from the cult of the Family. Rather than being a bond of affection, the Family in the East is seen as a wide-branching social hierarchy ascending from son to father, from father to grandfather, from grandfather to great-grandfather, and earlier ancestors. Ancestors never lose their importance or influence. On the contrary, they are vested with sacred authority and absolute power:

The private way of life, the state regime and religion, and the moral worldview of the Chinese all grew and developed from one common route, from the family principle, or more precisely, from the absolutism of paternal power ... The entire complex political organization of today's China is considered by the Chinese themselves as a concentrated expansion of paternal power. (Solovyov, 1890: 184)

The father of the family enjoys full power over his children while recognizing the full power of his dead father and the whole of his ancestry over him. Any virtue or any idea of order are based on filial respect of the forefathers, both living and dead. Thus, the Chinese never use personal autonomy or act in their own name; instead, they perform the will of their ancestors. Therefore, the Far Eastern civilization is oriented in the past, which determines both the present and the future. The Christian world, on the contrary, is intrinsically forward-looking.

Chinese society, while being incredibly cohesive, is completely alien to the humanistic universals of the West. However, Vladimir Solovyov is so suspicious of the unity which is typical of the Far Eastern civilization and contradicts European (Christian) values that he never questions the positive nature of brotherhood. Solovyov's ecumenical ideal can ultimately be reduced to the ideal of universal brotherhood of all people. At the same time, Solovyov offers an impressive image of brotherly unity of all people in the Far Eastern civilization, where individuality is superseded by forces of the clan.

The theme of brotherly unity is further developed in The Philosophy of the Common Cause by Nikolay Fyodorov (Fedorov). Despite Solovyov's enthusiastic reaction to Fyodorov's idea of the physical resurrection of ancestors (an idea that Solovyov, who named Fyodorov his teacher, accepted without reservation and interpreted as a project targeted at world brotherhood (Solovyov, 1995: 100-102), Fyodorov himself remained fairly sceptical about Solovyov's theory of undivided humanity (Fyodorov, 1995: 378-386). The idea of brotherly unity rejected by Vladimir Solovyov is central to Fyodorov's The Philosophy 
of the Common Cause and is associated with the Far Eastern civilization. Fyodorov's principal political idea is the development of the Russian-Chinese axis in continental Asia. The alliance of two ancient agricultural civilizations and their balanced friendly influence in Middle Asia must curtail the destructive energies of Turkic-Mongol "nomadism." In addition, there is an obvious similarity between Fyodorov's cult of forefathers and the Confucian cult of ancestors. This similarity integrates seamlessly into Fyodorov's global strategy of harnessing the blind forces of nature.

Fyodorov also provided liturgical rationale for the idea of brotherhood:

The very essence of the Liturgy of the Catechumens, adelphopoiesis, was ritualized as a brother-making ceremony; however, when detached from liturgy, adelphopoiesis lost public significance and became a private matter; brotherhood was now established between two individuals; likewise, baptism, which used to indicate the adoption of the child by the whole of the church community, transformed into a private affair when performed outside liturgy: the baptismal sponsors (i.e. godparents) were no longer seen as representatives of the church since they were appointed by the baptizand's parents, not the church ... Judging by the prayers used during the brother-making ceremony as well as the ektenes quoted by Goar, adelphopoiesis had universal rather than private significance as blessing for brotherly alliance was requested so that a human being may be created after the image and likeness of God and for the sake of apostolic alliance; only after that friendships between Sergius and Bacchus, Cosmas and Damian, Cyrus and John were remembered ... The brother-making ceremony is a perfect likeness of liturgy. (Fyodorov, 1995)

The key originality of Fyodorov's ideas lies in his dream of resurrection of every human being that has ever lived, which, in his opinion, was necessary to ensure sustained historical progress and victory over death. He was convinced that it would be possible to restore the state of the world before the Original Sin was committed by regulating nature through science and technology. Fyodorov described the current state of humanity as a "non-brotherhood." Death is an attribute of non-brotherly existence, where each life must be paid for by another person's demise. The blind, often hostile, forces of nature must be transformed into tools and organs for humanity by means of scientific discovery and human activity. By conquering nature, humanity will also conquer death. The harnessing of natural forces, the reformation of the human organism, space exploration, and the control of cosmic processes will enable humanity to raise ancestors, or "fathers," from the dead. The attainment of immortality is the "common cause" for all humanity. In humans, the resistance to the environment and the elements brings about an obsession with self-preservation, which results in hostile, "non-brotherly" relations between individuals and peoples. This hostility precludes the effective resolution of the vital problem of human dominance over nature. Fyodorov describes the social system based on egoism as "zoomorphic." Due to the conflict between knowledge and action, the caste of scientists engaging in pure and objectless contemplation generates a false understanding of the world and sets false priorities in scientific research. In a zoomorphic society, even great discoveries and inventions are used for a mutual struggle rather than the mutual 
good. Fyodorov believes that the ideal social system ("psychocracy") must be based on the unity of mind and action. When humanity learns to control the forces of nature and thereby putting an end to hunger, it will also eradicate the causes of enmity. Humanity will focus its efforts on the shared task of controlling nature on the planet, and even in the whole of the Universe.

Similarly to Khomyakov and Danilevsky, Fyodorov describes Western Europe as a global source of hostility resulting from conditions of human existence. Unlike Solovyov, who regarded German militarism as the only force capable of warding off "the yellow danger," Fyodorov interprets the militarist trends present in the development of Prussia (and, later, united Germany) as the principal threat to Russia and, more importantly, for the prospective return of humanity from non-brotherhood to brotherhood. Fyodorov is one of the few thinkers who warned that Germany would pose a danger to the European world, doing so two decades before World War I. Later, after the onset of the First World War, Nikolai Berdyaev wrote an article "The Prophecies of N. F. Fedorov Concerning the War," stressing that Fyodorov's prophetic visions had come true with surprising accuracy, and especially concerning Fyodorov's evaluation of the figure of German Emperor Wilhelm and his fatal role in world history (Berdyaev, 2008: 469-474). Germany as a leader of industrialized urban civilization is naturally hostile to Russia and humanity; whereas Russia relies on the Christian ideal of theanthropism, Germany gravitates towards the ideal of anthropotheism. The German spirit manifests itself most dramatically in Nietzsche, the philosopher of the Dark Kingdom, the prophet of Übermenschheit, the advocate of will to power, and the "philosopher of struggle and advocate for the extermination of the weak so that the new type, the Übermensch, could emerge" (Fyodorov, 1997: 118). Fyodorov names Emperor Wilhelm the Dark King who is destined to fulfill Nietzsche's projections.

It is noteworthy that Fyodorov was little concerned by the possible threat to the existence of the Russian state from the enmity between Russia and Germany. For him, any modern state was an embodiment of "non-brotherhood," and the Russian monarchy was no exception. The Russian state cannot be named the Fatherland since it has yet to become one. However, the Russian state has a special historical mission, and the Russia's gathering of lands and peoples was targeted at protecting the nation from the peril of nomadism.

Apart from the gathering of lands and peoples, the Russian state also performs a protective function, and therefore plays a positive role in restoring the brotherly condition. At the same time, the incomparable political might of the Russian state and the vast space and numerous ethnicities in care of the Russian Tsar acquires a special providential meaning as proof of the exceptional role Russia will play in "the common cause" of resurrecting ancestors and restoring the universal brotherhood of all people. Thus, Nikolay Fyodorov includes the concepts "brotherhood" and especially "non-brotherhood" in his unique scientific and religious theurgy, and fundamental reform of the laws of the universe. The concepts "friendship" and "enmity" are identified with the notions of brotherhood and non-brotherhood. This identification is determined by the whole evolution of 
the concept "friendship" in Russian religious philosophy, from Khomyakov, who saw the unity of monarchy with the people as the model of friendship, to Fyodorov, who believed that friendship and brotherhood were possible either in the prelapsarian state of humanity or as a result of the physical resurrection of ancestors. In any case, friendship and brotherhood are regarded as universal conditions encompassing all people.

The concept of brotherhood represented one of the fundamental political values in the ideological spectrum of the Modern Age, where three influential ideologies of nationalism, liberalism, and socialism could be singled out. These three ideologies correspond to the three principles of the French Revolution, Liberté, Égalité, Fraternité (Freedom, Equality, Brotherhood). The three ideologies recognize the importance of each of the concepts, yet differ in the understanding of their relative significance and hierarchy. Thus, liberalism does not reject equality or brotherhood, but claims that they can only be achieved through freedom. Socialism, in turn, stems from the belief that freedom and brotherhood can be attained through equality. In this framework, nationalism can be interpreted in a relatively neutral way, and does not necessarily have to be linked with national liberation or national separatism. Nationalism may be defined as an ideology based on the value of people's brotherhood in blood or "soil" (i.e., background, encompassing culture, history, and language), whereas freedom and equality are considered to be attainable only in brotherhood. The value of brotherhood may be construed in different ways as racial or ethnic unity or, more broadly, as social solidarity, with freedom and equality seen as derived from brotherhood.

As brotherhood (i.e., the ethnic unity of the Russian nation) directly or indirectly became the definitive value of nationalism as an ideology, new themes emerged that were fairly uncomfortable for the crown. First, the lower classes were declared as the carriers of supreme religious and moral values. In practice, the idea of the people as the epitome of spiritual health spawned the belief that the peasantry had preserved the unifying forces which may bring about the ideal of national brotherhood. Hence the second "uncomfortable" topic, which is the idea that the aristocracy is subject to the pernicious influence of values alien to Russian culture, and therefore acts as a barrier to the attainment of the national ideal. In this context, the ideas of world brotherhood favored by Russian philosophers can be interpreted as an antithesis to nationalism. This approach is best summed up by Dostoyevsky's well-known claim that a Russian will never agree to anything less than world brotherhood in Christ. The idea of world brotherhood could adopt quite unusual forms, such as Nikolay Fyodorov's philosophy of the "common cause," which involves escaping from the destructive urban civilization to space and other planets. The leading role of Russia in achieving world brotherhood is always associated with self-restraint.

Quite naturally, if a nation has "no specific objective," and "has no need in any special privileges," this may justify social apathy or an inclination towards social regress. Moreover, beliefs about a special historical mission of the Russian people may be used to rationalize the cruelest repressions on the part of the totalitarian regime, causing suffering primarily to Russians themselves. The idea that totalitarianism (so alien to Russian 
civilization) was supposedly transformed in keeping with traditional mentality is an acceptable logical consequence of Vladimir Solovyov's historiosophy.

Russian religious philosophy has put the idea of brotherhood in all its many forms to serious testing. This journey cannot be reduced to a single lonely movement in the catacombs of history, and its achievements have yet to be evaluated. Meanwhile, it may be useful to draw some parallels between Russian religious philosophy and some concepts of $2 \mathrm{O}^{\text {th }}$ century Western European philosophy, which continue to generate acute interest even today.

The first parallel can be drawn between Vladimir Solovyov's descriptions of individuality subsumed by collectivity and Max Weber's meditation on the "mystical acosmism of brotherly love" (Weber M., 1920). The mystical ethic of brotherhood as described by Weber is an ethic based on the rejection of inequality in the charismatic distribution of grace between members of the religious community, rather than a force alien to Christianity. Weber does not attribute the mystical acosmism of brotherhood to the non-Christian world; on the contrary, he links it with certain Protestant communes. Albeit rare, such communes do exist in Christendom and are usually built around a shared mystical experience:

\begin{abstract}
Wherever genuine mysticism gives rise to social action, such action is characterized by the acosmism of the mystical sentiment of love. In this sense, mysticism may exert a psychological effect on the formation of community in opposition to its "logical" conclusion. The core idea of the mystic oriental Christian church was a firm conviction that Christian brotherly love, when sufficiently strong and pure, must necessarily lead to unity in all things, even in dogmatic beliefs. In other words, the Christians who sufficiently love one another, in the Johannine sense of mystical love, will also think alike and, because of the very irrationality of their communal sentiment, act in a solidarity which is pleasing to God. (Weber, 1993: 175)
\end{abstract}

Later, Hannah Arendt connected the idea of the acosmic brotherhood with the historical destiny of the Jews. As Arendt points out, "acosmic" brotherhoods are inevitable in those periods described by historians as "dark times." However, acosmism generally results from forced exile rather than a free choice on the part of a given community. Historically, acosmic brotherhoods frequently emerged from enslaved "pariah" peoples, and groups such as the Jews. In sum, Arendt links brotherhood with the concept of "worldlessness," or the loss of the world for pariah groups. To some extent, this constitutes a return to barbarism; however, this return is preferable to group destruction. Brotherly attachment involves excessive closeness between people forming the brotherhood. For such brotherhoods, the world disappears twice, once as an unmeasurable external space, and again as the interspace within brotherhood, where freedom of personality is rendered impossible (Arendt, 1970: 13).

This interpretation of brotherhood is in stark contrast with the understanding of friendship. Indeed, the world which manifests itself fully in friendship and becomes a political world (the world of a polis) disappears in brotherly unity. However, human rela- 
tions in brotherhood acquires a special warmth, a certain archaic humanity springing from dark barbarism. This dark humanity, extending solely to the underprivileged ones, is inseparable from insult and injury. In addition, the idea of brotherhood exonerates people adhering to this idea from a responsibility for the world, and therefore

humanitarianism of brotherhood scarcely befits those who do not belong among the insulted and the injured and can share in it only through their compassion. The warmth of pariah peoples cannot rightfully extend to those whose different position in the world imposes on them a responsibility for the world and does not allow them to share the cheerful unconcern of the pariah. (Arendt, 1970: 16)

Brotherhood, which manifests itself in the darkness of worldlessness, makes insults and injuries bearable, but its political meaning, according to Arendt, is irrelevant. In the light of the public and the political, brotherhood may only pose as something it is not; it may only be a surrogate of friendship as genuine humanitarianism. In this context, it may be useful to undertake a retrospective analysis of Khomyakov's, Vladimir Solovyov's, and Nikolai Fyodorov's ideas of brotherhood, whereas the idea of world brotherhood may be perceived as an instinctive aspiration of Russian religious philosophy breaking away from the darkness of worldlessness as described by Hannah Arendt.

In retrospect, the obvious predominance of the idea of enmity over the idea of friendship in $19^{\text {th }}$ century Russian religious philosophy acquires a special significance. Naturally, this predominance cannot be interpreted as a symptom of some persecution mania affecting Russian philosophy. Carl Schmitt provides a key to the correct interpretation of enmity (Schmitt, 2007): as we know, he believed that the friend/enemy distinction is what marks the borderline between the political and the non-political. This foundational opposition lies at the heart of the political domain, for when this opposition disappears, the political vanishes with it.

The specific political distinction to which political actions and motives can be reduced is that between friend and enemy. This provides a definition in the sense of a criterion, but not as an exhaustive definition or one indicative of substantial content. Insofar as it is not derived from other criteria, the antithesis of friend and enemy corresponds to the relatively independent criteria of other antitheses: good and evil in the moral sphere, beautiful and ugly in the aesthetic sphere, and so on. In any event, it is independent, not in the sense of a distinct new domain, but in that it can neither be based on a single antithesis or any combination of other antitheses, nor can it be traced to these. If the antithesis of good and evil is not simply identical with that of beautiful and ugly, profitable and unprofitable, and cannot be directly reduced to the others, then the antithesis of friend and enemy must even less be confused with or mistaken for the others. The distinction of friend and enemy denotes the utmost degree of intensity of a union or separation, of an association or dissociation. It can exist theoretically and practically, without having simultaneously to draw upon all those moral, aesthetic, economic, or other distinctions. The political enemy need not be morally evil or aesthetically ugly; he need not appear as 
an economic competitor, and it may even be advantageous to engage with him in business transactions. Nevertheless, he is the other, the stranger, and it is sufficient for his nature that he is, in a specially intense way, existentially something different and alien, so that, in the extreme case, conflicts with him are possible. These can neither be decided by a previously determined general norm nor by the judgment of a disinterested and therefore neutral third party (Schmitt, 2007: 26-27).

In this understanding, enmity in Russian religious philosophy is not so much the opposite of friendship as a method to construct the political domain. If the political is understood in the Aristotelian sense of a shared space for joint action by friendly alliances (as opposed to diplomatic strife or court intrigues), the idea of enmity acquires new, unexpected connotations when juxtaposed with the concept of brotherhood. The ideal of world brotherhood is only possible in the political space which, as Khomyakov, Solovyov, and Fyodorov sense, is still non-existent. The figure of the common enemy opens possibilities for joint actions for friendly alliances; even Danilevsky, who leaves Russia alone face to face with hostile Europe, never ceases to hope for the emergence of a friendly alliance of all Slavs in the nearest future. The enemy is of importance as an external enmity disrupts the sleepy placidity of brotherhood and compels it to make the first steps towards global unity.

Construction of friendship policies in Russian religious philosophy is a highly versatile and, therefore, instructive experience. Naturally, the methodological inventory used in this construction suggested traditional metaphysical assignment of essences, an intellectual technique which had become obsolete by the $19^{\text {th }}$ century. Given this, the idea of world brotherhood contains a contradiction that is apparent today. However, the mental paths leading to this idea which were so fully explored by Russian religious are still attracting many thinkers. In this context, the evolution of Russian religious philosophy, a journey full of victories and defeats, will definitely remain a subject of interest.

\section{References}

Arendt H. (1970) On Humanity in Dark Times: Thoughts about Lessing. Men in Dark Times, New York: Harvest Book, pp. 3-32.

Aristotle (2004) Nicomachean Ethics, Cambridge: Cambridge University Press.

Berdyaev N. (2008) Prorochestva N. F. Fyodorova o voine [N. F. Fyodorov's Prophecies about War]. N. F. Fyodorov: pro et contra. Kniga 1 [N. F. Fyodorov: Pro et Contra. Book 1], Saint Petersburg: RCHI, pp. 469-474.

Blanchot M. (1971) L'Amitié, Paris: Gallimard.

Bulgakov S. (2003) Uteshitel [The Comforter], Moscow: The Accessible Orthodox University.

Chicherin B. (2009) Vospominania. Moskva sorokovyh godov [The Memories. Moscow of 1940s]. Slavyanofilstvo: pro et contra [Slavophilia: Pro et Contra], Saint Petersburg: RCHI, pp. 189-206.

Cicero (1913) On Duties (De Officiis), Cambridge: Harvard University Press. 
Danilevsky N. (2011) Rossiya i Evropa [Russia and Europe], Moscow: Terra.

Derrida J. (1994) Politiques de l’amitié suivi de Loreille de Heidegger, Paris: Galilée.

Filatova O. (2010) O russkom shellingianstve (problema zaimstvovania filosofskoi sistemy) [On Russian Schellingism (The Problem of the Adoption of Philosophical System]. Idei i idealy, no. 4, pp. 33-38.

Florensky P. (2012) Stolp $i$ utverzhdenie istiny: opyt pravoslavnoj teodicei $v$ dvenadcati pis'mah [The Pillar and Ground of the Truth: An Essay in Orthodox Theodicy in Twelve Letters], Moscow: Academic Project.

Florovsky G. (1991) Puti russkogo bogoslovia [The Ways of Russian Theology], Vilnus: Puti k istine.

Fyodorov N. (1995) Project soedinenia tserkvei [The Project of Integration of Churches]. Sobranie sochinenii. Tom 1 [Works, Vol. 1], Moscow: Progress, pp. 370-387.

Fyodorov N. (1997) Svjaschenno-nauchnyi materialism [The Sacral and Scientific Materialism]. Sobranie sochinenii. Tom 2 [Works, Vol. 2], Moscow: Progress, pp. 289-292.

Hegel (1975) Aesthetics: Lectures on Fine Art, Vol. 2, Oxford: Clarendon Press.

Ivanov V. (1994) O znachenii Vl. Solovyeva $v$ sudjbah nashego religioznogo soznania. Sbornik statei o Solovyeve [On Meaning of Vl. Solovyev in Fortunes of Our Religious Consciousness: Collection of Articles about Solovyev], Brussel: Life with God.

Kant I. (1991) The Metaphysics of Morals, Cambridge: Cambridge University Press.

Khomyakov A. (1994) O starom i novom [ On old and new]. Sochinenia. Tom 1 [Works, Vol. 1], Moscow: Medium, pp. 456-470.

Mailov A. (1997) O duhe nad vodami haosa [On Spirit above Waters of Chaos]. Razmyshlenia o haose [Reflections on Chaos], Saint Petersburg: Eidos. pp. 11-15.

Maslin M. (2016) Russkaia filosofia kak edinstvo v mnogoobrazii [Russian Philosophy as Unity in Diversity]. Tetradi po konservatismu, no 2, pp. 115-128.

Schmitt C. (2007) The Concept of Political, Chicago: University of Chicago Press.

Sizemskaya I. (2012) Russkaia filosofia istorii v poiskah tselostnosti istoricheskogo bytia (pervaia polovina XIX veka) [Russian Philosophy of History in Search of Wholeness of Historical Being (The First Half of the 19th century)]. Philosophical Sciences, no. 1, pp. $115-128$.

Solovyov V. (1890) Kitai i Evropa [China and Europe]. Sobranie sochinenii. Tom 6 [Works, Vol. 6], Saint Petersburg: Prosvetchenie, pp. 93-152.

Solovyov V. (1988) Danilevsky [Danilevsky]. Sochineniya. Tom 2 [Works, Vol. 2], Moscow: Mysl, pp. 406-413.

Solovyov V. (1995) Dva pisma Nik. Fyodorovu [Two Letters for N. Fyodorov]. N. F. Fyodorov: pro et contra. Kniga 1 [N. F. Fyodorov: pro et contra. Book 1]. Saint Petersburg: RCHI, pp. 100-102.

Solovyov V. (2007) Natsionalnyi vopros v Rossii [The National Problem in Russia], Moscow: Chranitel.

Vorobyeva S. (2015) Problemy russkoi filosofii v trudah Chizhevskogo [Problems of Russian Philosophy in Chizhevsky's Works]. Veche, no 2, pp. 208-217. 
Weber M. (1920) Gesammelte Aufsatze zur Religionssoziologie, Bd. I, Tübingen: Mohr Siebeck.

Weber M. (1993) The Sociology of Religion, Boston: Beacon Press.

\section{Политики дружбы в русской религиозной философии}

\section{Владимир Быстров}

Доктор философских наук, профессор Института философии

Санкт-Петербургского государственного университета

Адрес: Университетская набережная, д. 7/9, г. Санкт-Петербург, Российская Федерация 199034

E-mail:vyb83@yandex.ru

\section{Сергей Дудник}

Доктор философских наук, профессор, директор Института философии

Санкт-Петербургского государственного университета

Адрес: Университетская набережная, д. 7/9, г. Санкт-Петербург, Российская Федерация 199034 E-mail: s.i.dudnik@gmail.com

\section{Владимир Камнев}

Доктор философских наук, профессор Санкт-Петербургского государственного университета Адрес: Университетская набережная, д. 7/9, г. Санкт-Петербург, Российская Федерация 199034 E-mail: kamnev4@yandex.ru

Феномен дружбы еще в античности стал объектом пристального внимания со стороны философии. Аристотель в «Никомаховой этике» связывает с дружбой политическое существование человека, так как полагает, что и сам полис строится по аналогии с дружескими союзами. Цицерон также видел в дружбе прообраз социальности. Постепенно на смену такому представлению приходит романтическая концепция, где дружба понимается как субъективное, чувственное сближение индивидов, доступное весьма немногим. Романтической концепции придерживались и Кант, и Гегель. Русская религиозная философия, с одной стороны, формируется под воздействием немецкого романтизма и свойственного ему понимания дружбы, но, с другой стороны, сразу же возвращает концепту дружбы социальное содержание. У Хомякова дружба устанавливается прежде всего между властью и народом, и этот дружеский союз отличает русскую культуру от западноевропейской. Однако русскую религиозно-философскую мысль отличает стремление понять феномен дружбы не сам по себе, а в его связи с понятиями вражды и братства. Возникает образ братской сплоченности, с которым Вл. Соловьев связывает главную угрозу христианству, идущую от дальневосточной цивилизации, тогда как у Н. Федорова, наоборот, в братской сплоченности, сохранившейся в русской и в китайской аграрной общине, таится залог спасения от «небратского» Запада. Связь концепта дружбы и братства проясняется в XX столетии в западноевропейской мысли, в частности, в представлениях о «мистическом акосмизме братства» у М. Вебера и Х. Арендт.

Ключевые слова: дружба, политическое, вражда, братство, Россия, Европа, Восток, акосмизм 